\title{
ANALYSIS OF FACTORS CREATING THE INFORMATION SOCIETY IN POLAND, WITH PARTICULAR EMPHASIS ON THE ROLE OF E-SERVICES - PRESENTATION OF SELECTED RESEARCH RESULTS
}

\section{PIOTR GUTOWSKI}

University of Szczecin, Faculty of Management and Economics of Services, POLAND

e-mail: piotr.gutowski@wzieu.pl

\author{
\begin{tabular}{l|l} 
RECEIVED & 6 November 2018
\end{tabular} \\ ACCEPTED $\quad 3$ December 2018 \\ JEL \\ CLASSIFICATION \\ $011,039,052$
}

KEYWORDS $\quad$ information society, e-services, factors creating information

ABSTRACT In the article below, the authors presented an analysis of the factors that create the information society in Poland, with particular emphasis on the role of e-services. Selected results of the expert study were presented, which concerned the analysis of synergies between the observed digital revolution, general macroeconomic factors and phenomena and e-services, such as: the relationship between economic and social development and the development of the information society; the role of high-speed Internet in social and economic development; impact of selected IT services on the development of the information society; the power of influence of selected groups of entities on the creation and development of the IS (information society); perceived scale of benefit-cost ratio of stimulating the development of IS; assessment of the relevance of e-services and other services of a similar nature.

\section{Introduction}

The emergence of the information society has caused the expansion of the economic role of the services sector. The natural consequence of such change was the increase in employment in this particular sector. Innovators and entities operating in the areas of high technology and information management, realizing the inevitability of the progressive automation of production as well as the fact of the growing world population, were the first to decide 
to stimulate and monitor the ongoing social transformations in such a way that they would bring the greatest economic and social benefits. Most of these activities were based on appropriate direction of funds, development, implementation of development plans and strategies, and the creation of specialized clusters.

The role of technical conditions enabling information handling changes over time. Saying that technological progress is the initiator of information societies is indisputable. Currently, modern transmission media (such as fiber optics or wireless broadband networks), characterized by continuous accessibility expansion, have a pass band so wide that it is possible to provide all possible services and organizational solutions with it. It means that in order to further effectively support information development, attention and actions should be focused on the economic, social and organizational spheres.

The key to achieving this goal are dynamically developing e-services. They should be perceived as the most tangible effect of the strategy based on stimulating IS development. Some of them, such as e-government, in addition to being primarily directed at the wider society, create real opportunities to achieve social and economic benefits through the business sphere (e.g. in the form of facilitating and accelerating document exchange and reducing organizational costs) and public administration (e.g. in the form of improving the internal document circulation system). This demonstrates that e-services often have a multilateral dimension of impact.

\section{Methodology of the conducted expert research}

The information society is an interdisciplinary and complex structure. In order to study its essence and related components, the Delphi method was used, the essence of which is the transfer of accumulated expert knowledge, helping to see the hidden potential or solve the problem. The study was carried out in three stages. Initially, three key experts were appointed, who further serve as a team supervising the correctness of the conducted research and accepted the research assumptions, such as, for example, approving the assumed degree of consistency of the results obtained. In the second stage, a survey was sent to 19 experts. Due to the number of categories in questions, one critical value was assumed at the level of 0.7 with the consent of key experts. In the second stage, the compliance of experts was achieved. When analyzing the results, the principle of the greatest probability was followed, it means that the dominant indications were taken as the experts opinion.

\section{Presentation of selected research pesults}

Experts highly rated the association and interdependence between social development and the development of the information society. Based on Figure 1 it is determined that the direction of social development and the development of the information society is largely perceived as identical. Only less than $7 \%$ of specialists rated these two phenomena as inconsistent.

The most of specialists have assessed the Internet as important or very important in social and economic development (Figure 2). The answers provided indicate that the global intuitive communication network is an important factor stimulating the economy in the first place.

In the statement illustrating the impact of telecommunication services on the IS (Figure 3), the internet was again recognized as the service with the largest impact. Further places in the hierarchy took respectively: telephony (cellular and stationary) and television (understood as a service in all its variants). Smart buildings and housing estates (including related services) were considered as service with the least impact. GPS (Global Positioning 
System) along with other related navigation systems, was placed in the middle of the list, and their total impact was rated as medium, with a slight strong indication.

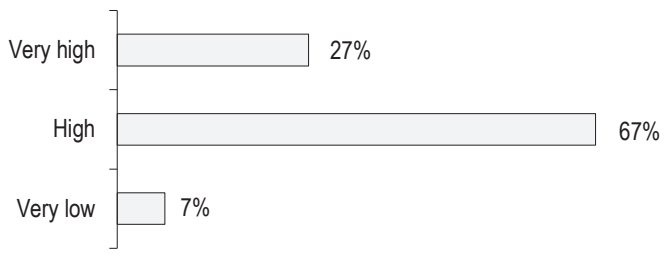

The results do not add up to $100 \%$ due to the rounding used.

Figure 1. The relationship between economic and social development and development of information society Source: own study based on the conducted research.

In social development

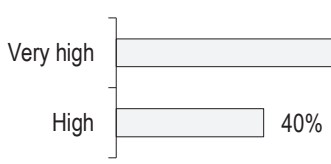

$60 \%$

$40 \%$
In economic development

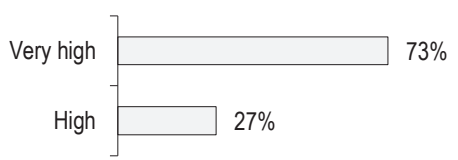

Figure 2. The role of high-speed Internet

Source: own study based on the conducted research.

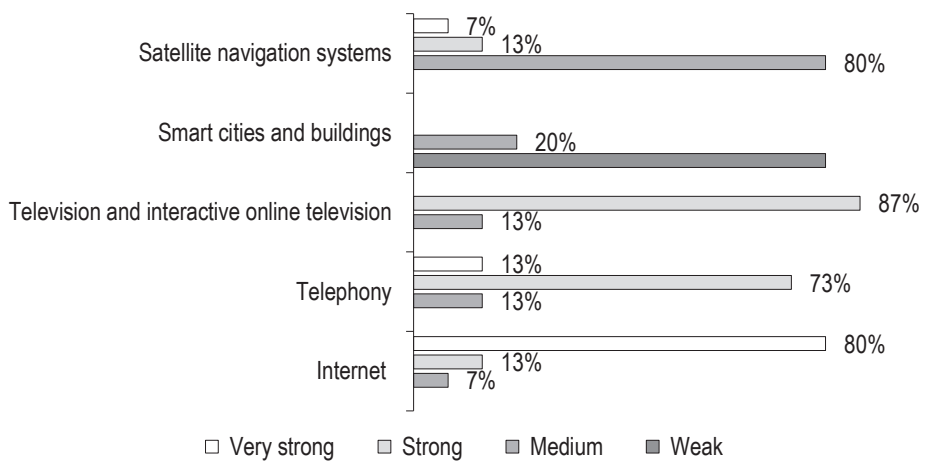

The results do not add up to $100 \%$ due to the rounding used.

Figure 3. Impact of selected telecommunication services on the development of the information society

Source: own study based on the conducted research. 
Figure 4 illustrates the results of the study of the impact of the main forces involved in IS development from the sectors point of view. Experts agree that the strongest development of IS is stimulated by the convergent ICT sector (Information and Communication Technologies) and the RD sector (research and development), which is unsurprising and in line with theoretical study (although the decreasing role of ICT can be expected in the near future because of achieving service market satisfaction). The Internet users, who are notably perceived as producers of ideas, knowledge and electronic content (prosumers of knowledge and services), have slightly weaker impact compared to the previous factors, however still on a strong and very strong level. Surprisingly, there is relatively low assessment of the role of development policy and development strategies, and it is worth mentioning that supporting the development of IS has become one of the EU's priorities, and thus also of Poland. Activities of the Polish Government focused on the development and implementation of numerous development strategies both nationwide and at the local government levels. As an example of this is the "Operational Program Innovative Economy 2007-2013" (Ministerstwo Rozwoju Regionalnego, 2007a, p. 128), Priority 8 - Information society - increasing innovation of the economy, Measure 8.4 - providing access to the Internet at the stage "last mile" for all voivodeships and Measure 8.3. - counteracting digital exclusion or the "Operational Program Digital Poland for 2014-2020" (Ministerstwo Inwestycji i Rozwoju, 2014). Another strategy that deserves attention was the "Operational Program Development of Eastern Poland 2007-2013" (Ministerstwo Rozwoju Regionalnego, 2007b, p. 81), whose efficiency in the field of IS can be presented as follows: $14,600 \mathrm{~km}$ of high-speed Internet network built, 1.04 million people received Internet access and 8,200 people were protected against digital exclusion through appropriate training and skills. Notwithstanding the foregoing, based on opinions of independent experts, the effectiveness and scope of the impact of state policy is losing significantly with the convergent, competitive ICT sector and telecommunication services operators, who in Poland took a role of leaders in creating a knowledgebased civilization.

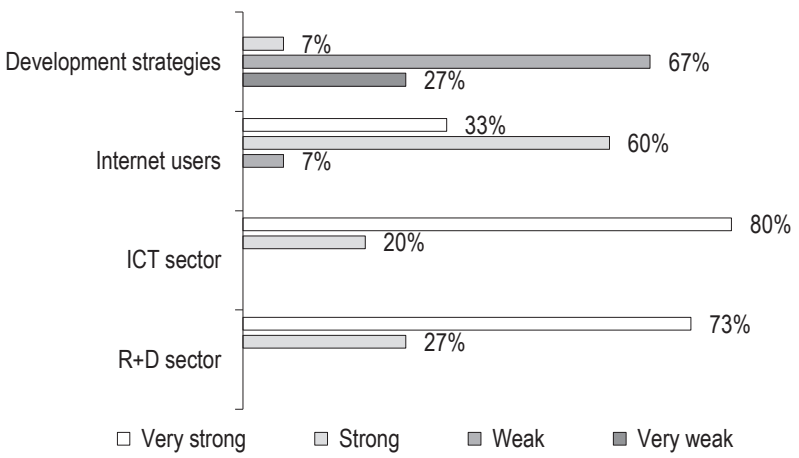

The results do not add up to $100 \%$ due to the rounding used.

Figure 4. The influence of selected groups of entities on the creation and development of information society

Source: own study based on the conducted research. 
Despite the poorly assessed effectiveness of government initiatives, surveyed specialists perceive IS stimulation as socially beneficial and economically viable (Figure 5). The costs incurred in connection with the developmental effort are estimated to be much smaller than the potential benefits that can be obtained.

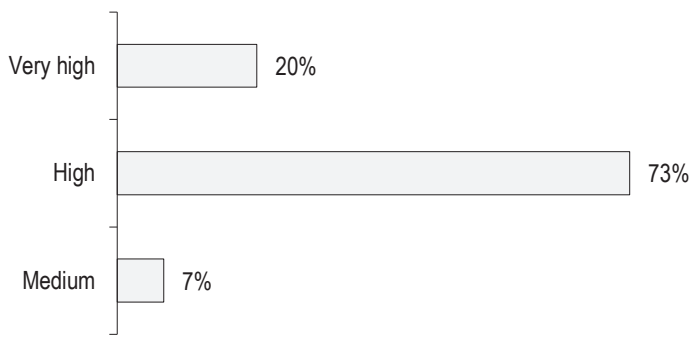

Figure 5. Perceived scale of benefit-cost ratio of stimulating the IS development

Source: own study based on the conducted research.

The ratio of the assumed profits to the costs was determined by $20 \%$ of experts as very high, by $73 \%$ of experts as high and by $7 \%$ of experts as average only. Such a favorable forecast, when confronted with poorly assessed assumptions of development plans, suggests the need, and even the necessity, to intensify real actions that could really lead to the IS development and its services, which ultimately form the basis of being in the modern world.

\section{The pole of e-services}

E-services enable more efficient and effective functioning of companies and stimulate the production and implementation of new products and services. The most common distribution channel is the Internet with its functionalities. It gives the opportunity to provide new forms of classic services (e.g. e-banking) or serves as a space for innovative ideas (e.g. virtual transport exchanges). The phenomenon of the Internet has made the digital revolution omnipresent and progressing. It affects almost all aspects of human life, which can be observed, among others in public administration, medicine, education, trade, finance, tourism, insurance, culture, etc. (Dabrowska, Janoś-Kresło, Wódkowski, 2009, pp. 41, 47).

An e-service can be defined as: "a service provided in a partially or fully automated way by information technology, using IT systems in public telecommunications networks, at the individual request of the recipient, without the simultaneous presence of parties in the same location and requiring little human participation on the side provider" (Ministerstwo Rozwoju Regionalnego, 2008). The ultimate goal of e-service is the same as traditional service: to meet the needs of man and increase his comfort of life. There are two main differences. The first of them (and at the same time the most characteristic) is the lack of distance barrier. The second is: partial or complete elimination of the human factor in the implementation process. (Flis, Szut, Mazurek-Kucharska, Kuciński, 2009, p. 4).

E-services have enormous development potential, and their further dynamic development can be predicted with high probability. Figure 6 presents the relevance assessment of services created by the IS and the Internet. The possibility of virtual enterprises, e-mail and social portals and thematic portals were recognized as the most 


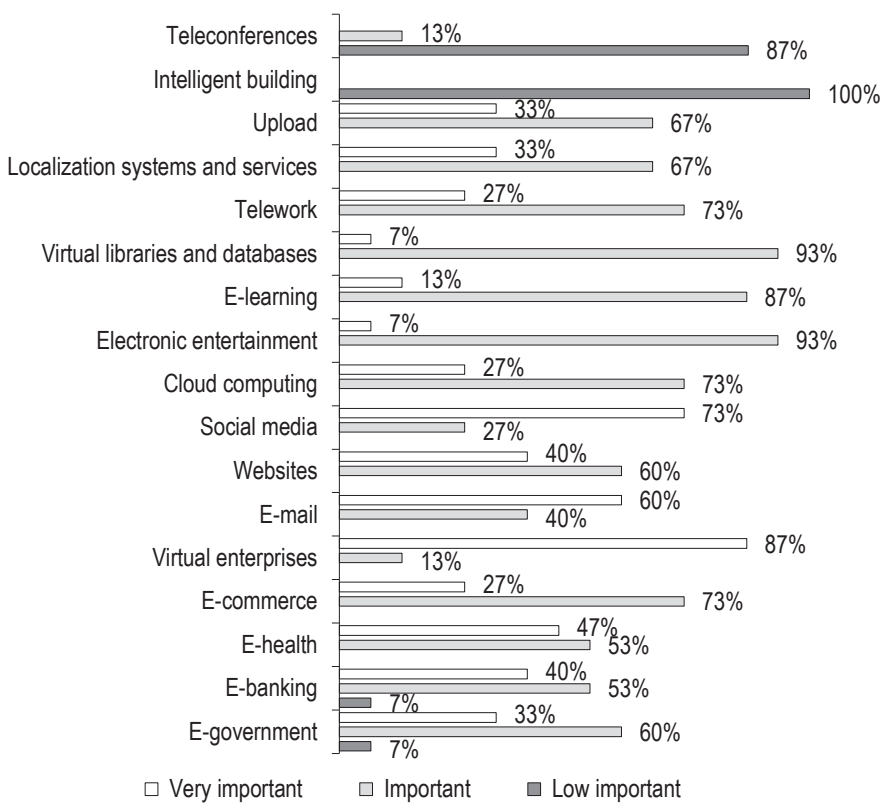

Figure $\boldsymbol{b}$. Significance assessment of e-services and other services of a similar nature

Source: own study based on the conducted research.

important services. Important and very important services were considered to be as follows: possibility of easy creating and publishing electronic materials, remote communication and location services, teleworking, virtual libraries and databases, e-learning, electronic entertainment, virtual cloud computing and databanks, websites, e-commerce, e-health, e-banking and e-government. Those which, according to the survey results, are characterized by the least impact on economic aspects, are: teleconferences and smart construction.

\section{Conclusions}

The efficiency of emerging information societies becomes one of the most important decision factors determining the economic condition of states. This is due to natural adoption of information into the group of classic economic production factors, taking into account that information is the currency of the modern world. The most tangible effect and at the same time the reflection of the advancement level of digital social transformations are e-services. They provide an opportunity to employ a growing world population, in a result, stimulating development of e-services is extremely important from an economic as well as social point of view.

This article presents the result of the expert study. In the age of omnipresent convergence, the studied area is extremely difficult to analyze, both technically and substantively. This is due to the large interdisciplinary nature of the studied phenomena, the dynamics of the changes taking place, and their dimension of impact, and thus the multitude of parties associated with them.

Drawing conclusions from the research, it can be stated that despite many initiatives supporting information techniques, their effectiveness in the eyes of experts on the subject is assessed poorly. According to experts, the 
potential benefits resulting from the acceleration of cyber-world development far outweigh the costs that need to be incurred to implement such initiatives. This determines the need for continuous and in-depth IS monitoring to define the reasons for the relatively poor effectiveness of development strategies.

\section{References}

Dabrowska, A., Janoś-Kresło, M., Wódkowski, A. (2009). E-usługi a społeczeństwo informacyjne. Warszawa: Difin.

Flis, R., Szut, J., Mazurek-Kucharska, B., Kuciński, J. (2009). E-usługi-definicja i przykłady. Badanie zapotrzebowania na działania wspierające rozwój usług świadczonych elektronicznie (e-usług) przez przedsiębiorstwa mikro i małe. Warszawa: PARP.

Ministerstwo Inwestycji i Rozwoju (2014). Program Operacyjny Polska Cyfrowa na lata 2014-2020. Retrieved from: https://www.mc.gov. pl/files/program_operacyjny_polska_cyfrowa_05122014.pdf.

Ministerstwo Rozwoju Regionalnego (2007a). Program Operacyjny Innowacyjna Gospodarka 2007-2013. Narodowe Strategiczne Ramy Odniesienia 2007-2013. Warszawa, październik. Retrieved from: www.funduszestrukturalne.gov.pl/NR/rdonlyres/ EDB3CC61-E376-46B2-913B-3F82EFFDC252/39246/POIG_01102008.pdf.

Ministerstwo Rozwoju Regionalnego (2007b). Program Operacyjny Rozwój Polski Wschodniej 2007-2013. Narodowe Strategiczne Ramy Odniesienia 2007-2013, Oś priorytetowa II - Infrastruktura społeczeństwa informacyjnego. Warszawa.

Ministerstwo Rozwoju Regionalnego (2008). Program Operacyjny Innowacyjna Gospodarka 8.3 i 8.4. Retrieved from: https://cppc. gov.pl/programy/poig/nabor-wnioskow-8-3; https://cppc.gov.pl/programy/poig/nabor; https://cppc.gov.pl/programy/popc-2/popolska-cyfrowa-1-1/nabor-wnioskow-popc-1-1.

Rozporządzenie Ministra Rozwoju Regionalnego z dnia 13 sierpnia 2008 r. w sprawie udzielania przez Polskę Agencję Rozwoju Przedsiębiorczości pomocy finansowej na wspieranie tworzenia i rozwoju gospodarki elektronicznej w ramach Programu Operacyjnego Innowacyjna Gospodarka, 2007-2013. Dz.U. 153, item. 956, § 3.1.

Cite this article aS: Gutowski, P. (2018). Analysis of factors creating the information society in Poland, with particular emphasis on the role of e-services - presentation of selected research results. European Journal of Service Management, 4 (28/1), 135-141. DOl: 10.18276/ejsm.2018.28/1-17. 